Przygotowana przez Dominikę Jagielską i Janinę Kostkiewicz praca warta jest lektury z kilku względów. Po pierwsze ze względu na prezentację myśli pedagogicznej Andrzeja Niesiołowskiego (ucznia między innymi Floriana Znanieckiego) i jednego z głównych przedstawicieli pedagogiki katolickiej dwudziestolecia międzywojennego w Polsce, o którym pedagogika polska przez wiele lat w zasadzie nie mówiła. Po drugie, ze względu na rekonstrukcję historii jednego z głównych nurtów pedagogiki, także współczesnej, jakim jest personalizm. Po trzecie, ze względu na studia porównawcze, wskazujące na subtelne dystynkcje między różnymi wersjami humanizmów i personalizmów, a także różnymi odmianami pedagogiki kultury. Po czwarte, ze względu na wiele wydobytych i przekazywanych ciekawostek (na przykład wątpliwości co do narodowości białoruskiej, jak też ukraińskiej), oddających stan wiedzy i poglądy popularne w okresie międzywojennym. Po piąte, omawiane studium uświadamia, jak ważna jest warstwa ideologiczna w kulturze i edukacji oraz jak istotne jest jej rozumienie przez osoby zajmujące się pedagogiką i wychowaniem. Wielu absolwentów studiów pedagogicznych nie zdaje sobie $\mathrm{z}$ tego sprawy, przeakcentowując zainteresowanie metodyką pracy z dzieckiem czy człowiekiem dorosłym na niekorzyść lektury, pozwalającej odnaleźć się w warstwie ideologicznej kultury i podejmować świadome zabiegi na rzecz jej poprawy poprzez edukację. Podsumowując, książka pt. Pedagogika humanizmu społecznego Andrzeja Niesiołowskiego warta jest polecenia zarówno teoretykom wychowania (i to nie tylko badającym historię myśli pedagogicznej), jak i osobom podejmującym pracę pedagogiczną, które próbują zrozumieć, a następnie udoskonalić, świat, w jakim żyją.

Jarostaw Horowski*

\title{
Stanisław Chrobak (red.), Ksiqdz, Bosko w wypowiedziach papieży, cz. II, Warszawa: Wydawnictwo Salezjańskie, 2015, s. 292.
}

DOI: http://dx.doi.org/10.12775/PCh.2015.038

Współczesna pedagogika zwraca uwagę na fakt, iż człowiek jest osobą będącą w nieustannym rozwoju. Aktualnie przyjęta koncepcja człowieka

* Dr Jarosław Horowski jest adiunktem w Katedrze Teorii Wychowania na Wydziale Nauk Pedagogicznych Uniwersytetu Mikołaja Kopernika w Toruniu. Adres: Wydział Nauk Pedagogicznych UMK, ul. Lwowska 1,87-100 Toruń; e-mail: jarohor@umk.pl. 
definiuje więc jego naturę w kategoriach osoby jako zintegrowanej całości fizyczno-psychiczno-duchowej z wszelkimi przynależnymi jej osobowymi właściwościami, takimi jak: jedność i integralność substancjalna, wolność, suwerenność i autonomia, rozumność, samostanowienie oraz godność. Każdy wymiar istnienia człowieka jako osoby niesie ze sobą szczególną wartość, zaś jego znaczenie jest jednakowo ważne dla konstytuowania jego istoty. „Struktura bytowa człowieka jest czymś absolutnie wyjątkowym w całej naturze-przyrodzie i dlatego nie może być redukowana do jednej strony swego bytowania - bądź do strony czysto psychiczno-duchowej (jak to Kartezjusz i niektórzy po nim chcieli widzieć człowieka), bądź do strony wyłącznie materialnej, zwierzęcej, lub jeszcze gorzej - do czystej struktury bezpodmiotowej, działającej ostatecznie (i bytującej) na zasadzie przypadku"1.

Współczesne rozumienie procesu edukacji odeszło już od traktowania go jako narzędzia przekształcania człowieka, ,zetknięcia się” ludzi, podczas którego wychowawca ,urabia” i kształtuje osobowość wychowanka. Stało się ono procesem ,zorientowanym na osobę”, w którym głównym celem wychowania jest ,uzdolnienie podmiotu (wychowanka) do przejęcia kierownictwa nad własnym procesem rozwoju" "; procesem wspierania rozwoju osobowości, który uwzględnia nie tylko aspekty naturalnego rozwoju człowieka, ale też relacje, zachodzące pomiędzy wychowaniem, kształceniem a tymże rozwojem, kierując się ku kreowaniu dojrzałej osobowości. Aktualnym celem tak rozumianej edukacji jest niesienie pomocy człowiekowi w procesie poznawania samego siebie i własnych możliwości w przekształcaniu środowiska. „W tak rozumianym wychowaniu nie ma wychowawców i wychowanków, ale spotykające się ze sobą osoby, które wzajemnie obdarowują się swoim człowieczeństwem"3.

Wielu pedagogów wspomina dziś św. Jana Bosko jako jednego z największych współczesnych wychowawców, twórce niepowtarzalnego i zadziwiającego aktualną skutecznością systemu wychowania, wiążącego się nie tyle $\mathrm{z}$ teorią, ile z praktyką wychowawczą. System ten oparty jest na dialogu, miłości i budowaniu wyższych wartości wychowanków. Stosowany jest on we wszystkich aktualnych salezjańskich dziełach wychowawczych

${ }^{1}$ Mieczysław Albert Krąpiec, Człowiek $w$ kulturze (Lublin: Redakcja Wydawnictw KUL, 1999), 22.

${ }^{2}$ Marian Nowak, „Pedagogika personalistyczna”, w: Pedagogika. Podręcznik akademicki, t. 1, red. Zbigniew Kwieciński, Bogusław Śliwerski (Warszawa: PWN, 2003 ), 55.

${ }^{3}$ Bogusław Śliwerski, „Wychowanie. Pojęcie - znaczenia - dylematy”, w: Wychowanie. Pojęcia - Procesy - Konteksty. Interdyscyplinarne ujęcie, t. 1, red. Maria Dudzikowa, Maria Czerepaniak-Walczak (Gdańsk: GWP, 2008), 50. 
i przynosi nieprawdopodobne, nawet w trudnej wychowawczo współczesności, efekty.

System prewencyjny zbudowany jest na trójmianie rozumu, religii i miłości, przy czym ostatni z tych elementów decyduje o skuteczności dwóch pozostałych ${ }^{4}$. W systemie tym relacje osobowe pomiędzy wychowawcą a wychowankami zajmują uprzywilejowane miejsce. Według św. Jana Bosko wychowanie musi opierać się na szczególnej postawie wychowawcy, jaką jest okazywana przez dorosłego, a odczuwana przez dziecko, pedagogiczna miłość, stwarzająca szczególną więź, która sprzyja interioryzacji wyższych wartości. Niełatwo jest oddać w języku polskim znaczenie używanego przez św. Jana Bosko włoskiego słowa amorevolezza. Zawiera ono w sobie opiekuńczość, czułość, łagodność, życzliwość, sympatię, dlatego w języku polskim przyjęło się uzupełniać tę miłość określeniem „wychowawcza". Amorevolezza nie jest zwykłą ludzką miłością ani też miłością nadprzyrodzona, jest złożoną postawą, czyniącą z wychowawcy osobę bez reszty oddaną dobru swoich wychowanków, w imię tego dobra gotową do wszelkich poświęceń i trudów. To uczucie składające się z ludzkiego ciepła, dobroci, delikatności, sympatii; przyjaźń głęboka i wiarygodna, zdolna do rozumienia, towarzyszenia, ubogacania innych własnym doświadczeniem ${ }^{5}$. To również tolerancja, wrażliwość, bezwarunkowa akceptacja, dążenie do głębokiego poznania problemów, trosk, potrzeb i radości wychowanka. Rozpatrywana $\mathrm{w}$ kontekście dwóch pozostałych filarów trójmianu oznacza poszanowanie drugiej osoby, podporządkowanie całego pedagogicznego działania jej ludzkiej wartości.

Szczególnie istotną i wielokrotnie podkreślaną przez księdza Bosko cechą amorevolezza, a jednocześnie genialną myślą wychowawczą jest refleksja o tym, iż wychowankowie nie tylko muszą być kochani, ale też muszą wiedzieć o tym, że są kochani. Miłość oraz oddanie muszą być więc okazywane w słowach, gestach, wyrazie oczu i twarzy, obecności pomiędzy wychowankami i okazywaniu ciepła, serdeczności, aby zostały przez wychowanków dostrzeżone i właściwie odczytane. Klimat pełen miłości i ludzkiego oddania jest wówczas podstawą do zaistnienia szczególnej relacji między wychowawcą a wychowankiem, w której to wychowanek zdolny jest do otwarcia się i zaufania.

${ }^{4}$ Por. Ksiadz Bosko w wypowiedziach papieży, cz. II, red. Stanisław Chrobak (Warszawa: Wydawnictwo Salezjańskie, 2015), 82.

${ }_{5}$ Por. Animator grupy młodzieżowej, red. Edward Pleń i in. (Warszawa: Wydawnictwo Salezjańskie, 1994), 57. 
Kolejnym elementem trójmianu jest rozum, przyjmowany przez księdza Bosko jako zdrowy rozsądek, postawa mądrości wychowawczej, dostrzeżenie i przyjęcie rzeczywistości młodych ludzi taką, jaka ona jest, z równoczesnym zaangażowaniem w zmianę tego, co wymaga naprawy. Zasada rozumności oznacza nieustanne odczytywanie rzeczywistości, co pociaga za sobą rozumowe przenikanie różnego typu zjawisk, zgłębianie siły ich oddziaływania i odkrywania w nich wartości ludzkich. Oznacza ona też bogata, jak również konkretną mądrość życiową, którą wychowawca stosuje w celu interpretacji zastanej rzeczywistości, a następnie projektowania działań wychowawczych.

Według św. Jana Bosko wszystko w wychowaniu powinno być rozumne. W opozycji do rozumu stoją namiętność, utrata kontroli nad sobą oraz nadmierna wrażliwość. Wychowanie oparte na rozumie zakłada więc stosowanie metody perswazji i dialogu na każdym etapie pracy wychowawczej - od elastycznego programowania wychowania w sposób życiowy i racjonalny, poprzez komunikowanie wychowankom swoich oczekiwań, aż do stawiania im adekwatnych celów i wymagań, zgodnych z ich możliwościami i potencjałem. W ujęciu Księdza Bosko rozum powinien być również podstawą wychowawczej miłości. Wychowanie oparte na miłości powinno być działaniem sprzyjającym asymilacji wyższych wartości. Miłość wychowawcza musi być miłością mądrą i wymagającą ${ }^{6}$.

Trzecim filarem systemu prewencyjnego św. Jan Bosko uczynił religię, przyjmując, że ostatecznym celem wychowania jest ukształtowanie człowieka wierzącego, a największym dobrem, jakim wychowawca może obdarzyć swoich wychowanków, jest prowadzenie ich drogą praktyk religijnych w kierunku zbawienia duszy. Człowiek dojrzały to wierzący obywatel, który odważnie wyznaje swoje przekonania religijne. Wychowanie młodego człowieka oznacza więc towarzyszenie mu z miłością wychowawczą w jego wzroście i dojrzewaniu, a także doprowadzenie go do momentu, w którym sam będzie mógł w wolny sposób wybrać drogę wiary. Dlatego niezbędna jest zachęta zarówno do pogłębiania treści religijnych, jak i uczestnictwa w praktykach religijnych. Zdaniem księdza Bosko jedynie religia jest zdolna doprowadzić do końca dzieło wychowania ${ }^{7}$.

Fundamentem i kwintesencją systemu prewencyjnego jest pojęcie asystencji, czyli współobecności wychowawcy wśród podopiecznych, która powstaje z miłości i troski o drugiego człowieka. Ksiądz Bosko uważał, że

\footnotetext{
${ }^{6}$ Por. tamże, 82-83.

7 Tamże, 83.
} 
wychowanek nie może być pozostawiony samemu sobie, bowiem jedynie stała obecność wychowawcy może zapewnić jego pełny rozwój i asymilację wartości, których wychowawca ma być nośnikiem, przykładem. Istotą asystencji jest nie tylko obecność fizyczna, ale też towarzyszenie w procesie dojrzewania, pomoc w odkrywaniu własnej tożsamości, nawiązywanie takiej relacji i więzi z wychowankiem, która rodzi więzy wzajemnego szacunku oraz zaufania, a tym samym pozwoli łagodnie prowadzić, czuwać i delikatnie korygować 8 .

Analiza wychowawczego trójmianu systemu prewencyjnego ukazuje pedagogiczną intuicję św. Jana Bosko, który, przyjmując rozum, religię i miłość za filary swego systemu, podkreśla wagę pełnego, integralnego wychowana człowieka. System ten w opinii wielu teoretyków i praktyków pedagogiki jest uznawany za ponadczasowy, ponieważ polega przede wszystkim na tworzeniu dialogicznej relacji wychowawca-wychowanek. Mimo iż system ten jest trudny dla wychowawcy, stawiający mu szczególne wyzwania, zarówno w przestrzeni rozwoju osobistego, jak też metodyki pracy wychowawczej, służy on wzrastaniu młodego człowieka do pełni dojrzałości.

W dwusetlecie urodzin Księdza Jana Bosko (1815-1888) publikacja Stanisława Chrobaka zachęca do ponownego odkrycia i zgłębienia propozycji wychowawczej św. Jana Bosko. W świetle współczesnych doświadczeń aktualnego życia pozostają bowiem nadal aktualne w kontekście naukowym i praktycznym te problemy, wobec których od początku swej działalności stawał ksiądz Bosko i które starał się rozpoznać i rozwiązać - kim są młodzi? czego chcą? do czego dążą? jakie mają potrzeby? Są to dziś problemy trudne, lecz nieuniknione, którym każdy wychowawca musi stawić czoło. Faktem jest, że system św. Jana Bosko uczy ,jak łączyć trwałe wartości Tradycji $\mathrm{z}$ »nowymi rozwiązaniami«, aby twórczo stawiać czoło pilnym potrzebom i problemom: nie przestaje być on mistrzem także w naszych trudnych czasach, proponując »nowe wychowanie«, które zarazem jest i twórcze, i wierne" . Dla księdza Bosko Ewangelia zawsze była żywą prawdą mobilizującą do tego, aby orędzie zbawcze stało się podstawą wychowania, było bodźcem stymulującym rozwój, punktem odniesienia w rozwiązywaniu różnorodnych kryzysów, przenikało wszystkie dziedziny życia.

Współczesny wychowawca musi umieć „uważnie i poważnie” dostrzegać specyfikę aktualnych uwarunkowań rozwoju młodych ludzi i zauważać pojawiające się wartości, które pociagają młodzież. W tym społecznym

8 Por. tamże, 283-285.

9 Jan Paweł II, Iuvenum patris, nr 13, w: Ksiadz Bosko, 85. 
i kulturowym kontekście przyjęcie wartości chrześcijańskich musi więc być rozumiane nie tylko jako użyteczne, ale też konieczne dla zbudowania dobrego społeczeństwa oraz prawdziwego, integralnego rozwoju ludzkiego. Przyszłość młodego pokolenia jest bowiem dla niego szansą i możliwością, które wypełnić trzeba określonymi treściami i wartościami. „Wychowanie jest sprawą serca - jak stwierdza ksiądz Bosko - i trzeba pozwolić Bogu wejść do serca młodzieży nie tylko przez bramę Kościoła, ale również przez bramy szkoły i warsztatu pracy"10.

Publikacja: Ksiąz Bosko w wypowiedziach papieży, cz. 2, zredagowana przez Stanisława Chrobaka, będąca kontynuacją cz. 1 - wydanej w ubiegłym roku, zawiera teksty papieży: Jana Pawła I, Jana Pawła II, Benedykta XVI, Franciszka na temat systemu prewencyjnego J. Bosko i jego osobistego charyzmatu. Z okresu krótkiego pontyfikatu Papieża Jana Pawła I nie można w niej odnaleźć bezpośrednich wypowiedzi o ks. Janie Bosko czy systemie prewencyjnym. Redaktor postanowił więc umieścić w niej tekst Albino Luciani (papieża Jana Pawła I) o św. Franciszku Salezym z 1972 roku. Całość opracowania zamyka List Ojca Świętego Franciszka w Dwusetlecie urodzin św. Jana Bosko z dnia 24 czerwca 2015 roku.

Publikacja stanowi wartościową naukowo propozycję uzupełniania naukowej wiedzy w kontekście opinii o wychowawczym znaczeniu systemu prewencyjnego św. Jana Bosko. Wypowiedzi i przesłania przedstawione przez papieży: Jana Pawła I, Jana Pawła II, Benedykta XVI i Franciszka przy różnych okazjach oraz w wielu częściach świata stanowią ważne i oryginalne tłumaczenie systemu prewencyjnego. Są także zaproszeniem skierowanym do czytelników (członków Rodziny Salezjańskiej, rodziców, wychowawców, pedagogów), by poznawać system prewencyjny z uwzględnieniem współczesnego kontekstu kulturowego i społecznego.

Lidia Marszatek*

10 Jan Paweł II, Iuvenum patris, nr 20, w: Ksiadz Bosko, 92.

* Dr hab. Lidia Marszałek, prof. Pedagogium, kieruje Zakładem Wychowania Przedszkolnego i Nauczania Początkowego w Instytucie Nauk Społecznych Wyższej Szkoły Nauk Społecznych Pedagogium w Warszawie. Adres: Pedagogium WSNS, ul. Marszałkowska 115, 00-102 Warszawa; e-mail: lidia.marszalek@gmail.com. 